\title{
In chains, yet prophetic! An African liberationist reading of the portrait of Paul in Acts 27
}

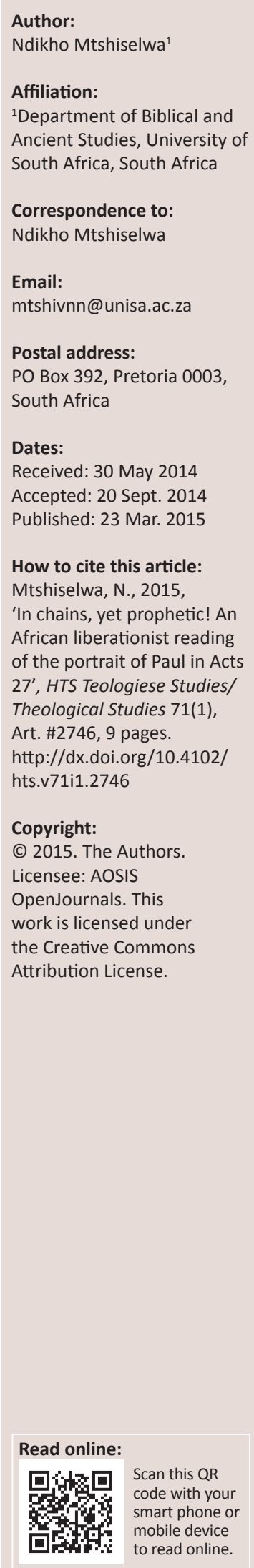

New Testament scholars have argued that Luke-Acts presents an apologetic historiography and political propaganda which portrayed Roman officials as saviours of the world. The problem with the discourse on the apologetic historiography and political propaganda in Luke-Acts is that the presence of various forms of oppression behind and in the text becomes hidden. Thus, it is pertinent to highlight the reality of oppression as well as the prophetic voice that responded to them, as illustrated by the text of Acts 27. In this article, Lucky Dube's Mickey Mouse freedom song is employed as a hermeneutical tool to unlock the meaning of Acts 27, and to argue that whereas Acts 27 contains an apologetic narrative, Paul's prophetic voice is equally evident in the chapter. From an African liberationist perspective, lessons are therefore drawn from Acts 27 regarding the liberationist prophetic voice of Paul. In the end, this article sees Paul's prophetic voice as an embodiment of both resilience and resistance in the face of imperialism and chains (oppression).

\section{Introduction}

In a remarkable book, Biblical Hermeneutics and Black Theology in South Africa, Mosala argues for a liberationist reading of the Bible and of ancient texts:

Texts that are against oppressed people may be coopted by the interlocutors of the liberation struggle ... the fact that these texts have their ideological roots in oppressive practices means that the texts are capable of undergirding the interests of the oppressors even when used by the oppressed. In other words, oppressive texts cannot be totally tamed or subverted into liberative texts. (Mosala 1989:30)

Based on Mosala's (1989) statement above, the text of Acts 27 can be approached from the perspective that the Bible can be read in a way that serves the interests of either the oppressor or the oppressed. In Luke-Acts, Gilbert (2003:236-239) identifies apolitical propaganda which rhetorically portrayed the Roman officials as saviours of the world. Interestingly, such strategic propaganda was meant to provoke conformity and loyalty to the imperialist Roman authorities. However, the problem with the rhetorical strategy, that is, the political propaganda at the time of the Roman Empire in the context of early Christianity is that it distracts Luke-Acts readers from the harsh reality of the various forms of oppression in Luke-Acts. The presence of this rhetorical strategy explains in part why Luke-Acts is often viewed by New Testament scholars as a form of apologetic historiography (Sterling 1992:386; Kelber 2004:147).

However, by regarding Luke-Acts as an apologetic narrative one might be tempted to argue, for example, that Acts $27^{1}$ is sympathetic to the cause of the imperialist Roman Empire. By implication, such an argument would suggest that Luke was not intentionally highlighting various forms of oppression and the prophetic voice that spoke against such oppression in Acts 27. Therefore, it is critical to investigate, firstly, the possible context or audience of Acts 27; secondly, whether Acts 27 represents an apologetic narrative; and thirdly, the portrait of Paul who, although in chains (of oppression), remained prophetic. In the end, this article seeks to draw lessons from Acts 27 and the liberationist prophetic voices which the oppressed can articulate in the context of oppression.

A critical question to ask is: what tools can be used to construct liberating lessons from Acts 27 which would highlight the reality of both the various forms of oppression as well as the liberating prophetic voice in the text? The article, 'Towards an Indigenous (Xhosa) South African Biblical Scholarship', by the author appears relevant. In the article, I examined how indigenous songs can be used to unlock or interpret an ancient text (Mtshiselwa 2011:668-689). Also, in the field of theology, several scholars have employed African biblical hermeneutics to interpret ancient texts. For her part, Masenya (Ngwan'a Mphahlele) (2001a:186-199; 2001b:145-157) demonstrates how Sotho proverbs could be utilised in South Africa biblical scholarship (cf. Sugirtharajah

1.As universally accepted, the book of Acts is the second part of the double volume - Luke-Acts (Ottermann 2007:111; Scheffler 2013:136). 
1999:100). Furthermore, she decisively employs a liberation song, 'Senzeni $n a$ ', to critique injustices both in the biblical and South African context (Masenya [Ngwan'a Mphahlele] 2008:114). Moreover, Nkoala's (2013:54) view that liberation songs generally serve as the means to articulate injustices which were in a form of poverty and exploitation, for instance reminds one of Lucky Dube's song, Mickey Mouse freedom.

As such, in line with the attractive manner in which African biblical scholars employed liberation songs to critique ancient texts and modern contexts, this paper will employ an African historical struggle song as a hermeneutic tool to unlock the meaning of Acts 27. The liberationist tenor underlying Mickey Mouse freedom, will be employed to interpret the situation of Paul who was in chains but remained prophetic in Acts 27. As will be shown below, a link between the context of the song and that of Acts 27, namely, a pre-liberation state is noticeable. The song was written in 1992, in a pre-liberation state of South Africa. Furthermore, the evidence of forms of oppression in the post-1994 South Africa, could reasonably link the song to the situation that is still in a pre-liberation state in Acts 27. In the album, House of exile (Remastered), the song, Mickey Mouse freedom, ${ }^{2}$ captures not only the realities of the post-apartheid South Africa, but also Lucky Dube's ideology of freedom and the tenor of liberation:

Put his coat on his shoulders and slowly he walked away

Behind him, he could hear

Those innocent voices

Crying out so bitterly, saying

We did not start the war

But we fighting now

We did not start this fire

But we burning now

They were told many years ago that their country is free

But they didn't understand

that it's not real

They never knew

It was a Mickey Mouse freedom, yeah (3x)

It is a Mickey Mouse independence, yeah (3x)

Me come in a you country, he (that) is said to be free (x2)

Me sight corruption

Me sight starvation

Walking like a millionaire, 'cause you think you country is free.

One thing you don't know, your country, he is being remote controlled

It was a Mickey Mouse freedom, yeah (3x)

It is a Mickey Mouse independence, yeah (3x)

\section{A possible Sitz-im-Leben of Acts $27^{3}$}

The consensus is that the life-setting of Acts 27 could be related to the time of the Roman Empire, between $\mathrm{AD}$ 80 and AD 120 (Pervo 2006:343; 2008:5). If the tenor of liberation underlying Mickey Mouse freedom includes both

\footnotetext{
2.Dube's song which is a revised version of Mickey Mouse freedom, was first released .Dubers of exile (Remastered), was later released on 14 September 2012 by Gallo Record Company, and is available at: http://www.youtube.com/watch?v=9jOem_FpjLY
}

3.Sitz-im-Leben is a German term which refers to the life-setting of a text. a concern and a protest against forms of oppression, it could help to investigate the forms of oppression that were inflicted by the Roman Empire on the early Christians in order to throw light on the likely Sitz-im-Leben of the text under discussion. On the oppression that was inflicted by the Roman Empire, Kelber (2004:137) identifies 'excessively punitive taxation, growing discontent and recurrent protests, mass crucifixions as political deterrent ...' (cf. Gilbert 2006:83). Unlike Kelber, Gilbert's claim appears implicit, as he does not clearly state the forms of oppression that were experienced by the early Christians during the Roman rule. Nonetheless, it is difficult to dispute the reality of different forms of oppression experienced by the early Christians under Roman rule, as textual evidence shown below will confirm.

Firstly, on the issue of the payment of taxes in Luke-Acts, Luke 20:21-26 makes it clear that the Jews were obliged to pay taxes to the Roman emperor: 'Then render to Caesar the things that are Caesar's ...'. Although the forceful payment of excessive tax, in particular, is evident in the first part of LukeActs, namely in Luke, it is however not so clear in the book of Acts, particularly in chapter 27. But if the Roman Empire was still in power at the time of writing Acts 27, then the payment of taxes must have persisted also. Besides, there is no evidence that the Roman Empire stopped demanding taxes from the early Christians. In fact, the empire continued to hold sway over the early Christians. Furthermore, as in Luke 20:21-26, reference to Caesar is present in the historiography of Luke in Acts 25:11,21, which strengthens the claim that the payment of taxes to Caesar or the Roman Empire remained in force at the time of Acts 27. Thus, the fact that early Christians were forced to pay tax reminds one of the lyrics of the song, Mickey Mouse freedom, 'One thing you don't know, your country, he is being remote controlled'. The liberation song, when considered in the light of the payment of taxes in the historiography of Luke in Acts confirms the imperialist influence of the Roman Empire on the early Christians and Christianity.

Secondly, Mickey Mouse freedom is a protest song of liberation that can be used to probe some of the recurrent protests during the Roman rule. In Luke-Acts, Paul's preaching is said to cause uprising in various cities as exemplified by the

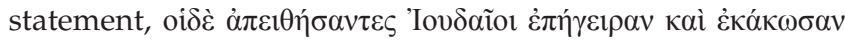

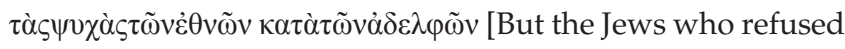
to believe stirred up the Gentiles and poisoned their minds against the brothers] (Ac 14:2). ${ }^{4}$ Paul was also stoned in the protest by the Gentiles in Acts 14:19, whilst in another instance, a protest against Paul and Silas led to their arrest, and they were presented to the Roman authorities (Acts 16:19). In this instance, however, it seems that Paul and Silas caused the uprising, hence, the complaint to the Roman authorities; 'These men are Jews, and are throwing our city into an uproar' (Ac 16:20). The protest was not against the Gentiles, per se, but by the Gentiles - the Jews stirred 
them up. Luke also reported that a riot was started in Acts 17:5, whilst, in Thessalonica the Jews also began a protest in which the crowds were agitated and stirred up when they learnt of Paul's presence and teaching in Berea (Ac 17:13). Furthermore, a protest erupted in Ephesus because of Paul's testimony (Ac 19:28).

Interestingly, in all these protests, it is difficult to find a clear complaint against the Roman Empire, that is, in terms of wrongdoing on the part of the empire. Instead, the protests seem to be against Paul, a member of the early Christian church. Therefore, the recurrent protests in Luke-Acts would not share the tenor of the protest that is articulated in Mickey Mouse freedom, which protests against forms of oppression. However, to appreciate the song, the protests in Luke-Acts would have to be viewed as a presentation of the struggles of the early Christians in the context of Roman imperialism. In other words, to some extent, the tenor of the song allows us to view the recurrent protests during the Roman imperialism as a projection of the struggle of the early Christianity.

Thirdly, a discussion of the subject of mass incarceration and crucifixion is pertinent, as it could provide evidence of yet another form of oppression during the Roman imperial rule. It was not uncommon for the Roman authorities to crucify people whom they considered a threat to their rule. In fact, the crucifixion of Christ and the two thieves attests to the trend of mass crucifixion conducted by the Roman Empire, as also indicated in the book of Acts $(2: 23 ; 10: 39)$. Similarly, an unspecified number of Jewish prisoners were crucified after the revolt that followed the dispute between Jews and Samaritans in Caesarea (Green 2004:61; cf. Josephus, Wars 2.12.6.). Thus, it is clear that at the time of the Roman Empire, mass incarceration and crucifixion was rife, showing that one cannot rule out the possibility that the acts were meant to scare the early Christians and manipulate them to be loyal to the Roman Empire.

The crucifixion of yet another Christian, in this instance, a church leader is reported by Christian tradition. Apostle Peter was crucified head down in Rome under Emperor Nero (Forbush 1926:4; Redekop 1993:16, 19; Pesthy 1998:123-124,130). Forbush differentiates between the deaths of Paul and Peter. Peter was crucified because he was not a Roman citizen, whilst Paul, a Roman citizen, was beheaded (Forbush 1926:4). This distinction shows the crucifixion of a non-Roman citizen. The portrayal of oppression in the mass incarceration and crucifixions would interest the composer of Mickey Mouse freedom, as it points to the need for liberation. Based on the tenor and caution on how people might not be free rendered by such a song, one cannot argue that the audience of Luke-Acts was truly free, if mass incarceration and crucifixion indeed took place. The type of freedom they experienced could also be described as a 'Mickey Mouse freedom' mainly because the reality of the acts of incarceration and crucifixion suggests that indeed there was no true freedom or liberation for the early Christians.
On the issue of clues that could point to the Sitz-im-Leben of Acts 27, it might be helpful to examine the phrase, 'without food', which is repeated in Acts 27 and used in the context of the breaking of bread and sharing food. It occurs first in verses 21 and 33, followed by the breaking of bread (Ac 27:35). It is doubtful that the repetition of the phrase is coincidental, as the repetitive style is often used to stress a certain point in literature. In the article, 'Waiters or Preachers: Acts 6:1-7 and the Lukan table fellowship motif', Pao (2011:136-139, 144) examines the motif of 'Lukan table fellowship' in his construction of the life-setting of Luke-Acts. The motif reveals a protest against the ill-treatment of the poor, sinners and widows, and especially against the exclusion of widows (Ac 6 and Lk 20:46-47). Pao explains that:

In Luke 20:46-47, for example, the widows are the objects of the oppressive acts committed by the 'scribes'. The adjectival modifiers $\pi \varepsilon v 1-\chi \rho \alpha \dot{~} v$ ('poor') and $\pi \tau \omega \chi \eta$ ('poor') that are attached to the widow of Luke 21:2 also identify this group as the lowly outcasts who are expected to experience the eschatological reversal proclaimed by Jesus (Luke 4:18; 6:20; 7:22; 16:19-31), and 'the poor' (oi $\pi \tau \omega \chi o i$ ) are specifically promised to be able to participate in the eschatological banquet (Luke 14:13, 21). In light of Luke's portrayal of the widows, the connection between Luke 5:29-31 and Acts 6:1-7 becomes clear. (Pao 2011:138)

Luke-Acts reports acts of protest against the exclusion and oppression of poor widows at the time of the Roman Empire, suggesting that the 'Lukan table fellowship' motif seen in the breaking of bread and sharing of a meal in Acts 27 could help illuminate the life-setting of Luke-Acts. Thus, it is reasonable to argue that the exclusion of widows, the poor and the outcasts constituted in part the context of Acts 27. The concern for the poor in the 'Lukan table fellowship' motif resonates with the tenor of Mickey Mouse freedom, as indicated by the line, 'Me come in a you country, he (that) is said to be free ... Me sight starvation'. Furthermore, Luke's concern for the oppressed, particularly for the poor, is strongly articulated elsewhere in Luke-Acts (Larkin Jr 2000:410; LobaMkole 2005:301; cf. Lk 1-2; 14:21). Loba-Mkole (2005:301) notes that Luke presents God as the one who elevates the poor who are oppressed (cf. the account of Jesus' birth in Lk 1-2). Thus, it would be difficult to dispute a setting that was devoid of poverty in the writing of Luke-Acts.

Luke-Acts also places poverty and the concern for the poor at the heart of the Gospel. This observation is supported by the inclusion of the 'poor, the crippled, the blind and the lame' in the eschatological banquet (Pao 2011:134; cf. Lk 14:21). Once more, the 'Lukan table fellowship' motif appears in Luke 14:21. In view of the use of the motif in Acts 27 as well as elsewhere in Luke-Acts, it is therefore evident that the challenge of poverty and the exclusion of certain groups of people constitutes the Sitz-im-Leben of Acts 27. In other words, the expression, 'without food' probably points to the need for the sharing of resources as well as to a protest against the exclusion of other people, namely the widows, poor, lame and the blind. Therefore, in all probability Luke also had the concern for the poor in mind in Acts 27. The concern for the poor in Luke-Acts is also interconnected with 
other forms of oppression and aspects of human suffering, such as 'physical and mental illness, social ostracism (women, children, members of despised professions) and political enmity' (Scheffler 2013:136). ${ }^{5}$ Scheffler's view lends credence to the claim that poverty indeed forms part of the Sitz-im-Leben of Acts 27.

Thus, it is difficult to disagree with Kelber that the clues in Luke-Acts about punitive taxation, growing discontent and recurrent protests and mass crucifixions which served as a political deterrent are compelling. The view that the challenge of poverty and exclusion of other people, namely the widows, sinners, poor, lame and the blind form part of the life-setting of Luke-Acts including Acts 27 strongly suggests that there was a need for sharing of resources which could have benefited and elevated the poor from the scourge of poverty. It is also clear that determining the possible Sitz-im-Leben of Acts 27 in the light of Mickey Mouse freedom, could unlock the reality of various forms of oppression. Considering the re-construction of the possible context of Acts 27, it becomes pertinent to establish whether Luke convincingly addressed the perturbing challenges faced by the oppressed early Christians. At issue is the argument that Luke was probably apologetic in presenting the historiography in the book of Acts and found it difficult to address the perturbing forms of oppression which his original audience, the early Christians, experienced.

\section{An apologetic narrative - conforming to imperialism?}

Kelber (2004:147) claims that the book of Acts was written from the perspective of a Christianity that had settled in the capital of Rome (cf. MacDonald 2012:52). Luke was expected to construct a narration that would negotiate the terms of settling in Rome: that is, the settlers in Rome could not jeopardise their peaceful stay by presenting a gospel or historiography that would challenge Roman imperialism. Some Luke-Acts commentators have noted that in Luke's narrative in Acts, the church moved from Jerusalem to Rome. On the book of Acts, Nasrallah comments that, 'Christianity is propelled from the margins of empire and the centre of Judaism, namely Jerusalem, to the center of the empire, which was Rome' (Nasrallah 2008:534; cf. Pervo 2000:38; Gregory 2003:353). Although this claim appears compelling, it does not clearly show that the early church and early Christian writers such as Luke were being controlled by the Roman Empire. Nasrallah and the other scholars have not considered the possibility that the early Christians were influenced by Roman imperialism, and this had implications for the writing of ancient texts, as will be argued below. It implies that the authors of early Christian texts could not exercise freedom of expression.

Since Acts 27 does not explicitly or convincingly address the challenges that its audience faced, it could be that Luke could

\footnotetext{
5.Like Guthrie (1970:90-92), Scheffler (1993:61-102) also comments on Luke's concern for the poor.
}

not freely write what he wanted, as this would put him in the spotlight and made him a target of Roman persecution, and the response to the challenge of taxation, protests, mass crucifixions and poverty would have challenged the empire. The assumption that the early writers of the New Testament were constrained and could not write freely under the imperialist rule, would be an interesting one if made in the light of Mickey Mouse freedom. At issue is the point that the early writers such as Luke were to some extent 'remote controlled', and that Luke was apologetic in his writing because he was probably under Roman surveillance.

The claim that Luke-Acts (including Acts 27) is a type of apologetic historiography is not surprising, but it indicates that the book of Acts appears to be sympathetic to the Roman Empire instead of being radical and explicit in opposing contentious issues that were oppressive to the early Christians (Sterling 1992:386; Kelber 2004:147). In fact, elsewhere in Luke-Acts, Paul is said to identify himself as a Roman citizen by birth (Ac 22:25-29; 23:27). This observation seems to lend credence to Kelber's (2004:147) position that Luke often made a case for a Christianity that was compatible with Rome. Roman imperialism presumably made it difficult for the early church to be prophetic; instead, the church eventually conformed to and pleased the empire. As a result, early Christian writers such as Luke also found it difficult to resist the temptation of conforming to the empire, as they became apologetic in their writing.

In fact, the mass incarceration and crucifixions possibly served to instil fear in people including the early Christian writers, especially those who sought to challenge the empire. Interestingly, Lucky Dube also seemed to challenge the authorities in his context with Mickey Mouse freedom. Gilbert (2006:85) points out that Paul tended to be sympathetic towards the Roman Empire because of the privileges he enjoyed as a Roman citizen. If one understands Gilbert correctly, the fact that Paul argued a case for his Roman citizenship shows that he must have sought acceptance and peaceful settlement in Rome. Gilbert (2006:85) argues that in the same vein, Luke attempted, 'to present Christians and Christianity as harmless and supportive of or at least neutral toward imperial rule' in Luke-Acts. In other words, Christians were portrayed as capable of living peacefully with the imperial Rome, irrespective of whatever form of oppression it inflicted on the Christians. Thus, instead of making prophetic declarations of the fall of the Roman Empire and the demise of imperialism, Luke in Luke-Acts appeared to support the empire (Gilbert 2006:86). However, caution should be exercised in arguing that early Christian writers, especially the writer of Acts 27, were sympathetic towards the empire. Below, an attempt will be made to show that Paul's stance was prophetic in Acts 27.

Outside the book of Acts, Paul charged his readers to be subject to the governing authorities (cf. Rm 13:1). Some scholars are of the view that in Romans 13:1, Paul had the Roman authorities in mind (Fitzmyer 1992:662-664; Gilbert 2006:84). Therefore, it seems that many early 
Christian writers, including Paul in this instance, found it difficult to distance themselves from the government of the Roman Empire but, to some extent, conformed to Roman imperialism. Hence, Paul urged the early church to submit to Roman rule. In this instance, it seems Paul was also apologetic, which suggests that the tendency to be apologetic was not uncommon in early Christian literature. Therefore, what we have in Luke-Acts is a typical trend in which the writer steers clear of explicitly and radically articulating the reality of oppression. Such a trend calls to mind the lyrics of Mickey Mouse freedom:

They were told many years ago that their country is free.

But they didn't understand that it's not real.

They never knew ...

Dube's song cautions us that a portrayal or narration of freedom might not always be a reliable presentation of reality. Obviously, the song refers to the South African context, and presupposes that the country does not appear to be completely free or liberated. Because of the various forms of oppression that prevail in the post-apartheid South Africa, it is difficult to argue that the country is holistically free. Oppression in South Africa manifests as socio-economic injustice signified by poverty and economic inequality, the imperialism of masculinity in the nation's politics, and restrictions on the church's prophetic witness. According to the song, socio-economic injustice, imperialism in terms of being dominated by others, and corruption, all point to the possibility of an unreliable narrative of liberation. That is, a country can appear to be free whilst in fact it is still faces the challenges of oppression. Therefore, Luke might have been apologetic in narrating his historiography, but that narrative contains evidence of various forms of oppression and of a prophetic voice, as will be argued below.

We have seen that the Sitz-im-Leben of Acts 27 was characterised by punitive taxation, growing discontent and recurrent protests, and mass crucifixions which served as a political deterrent to the early Christian writers. Furthermore, the people were threatened by the challenges of poverty and exclusion, especially widows, sinners, poor, the lame and blind, which resulted in a protest over the sharing of resources. That Luke is silent about the Roman tax requirements, protests in the Roman cities, mass incarceration and crucifixions, and poverty in Acts 27, shows that he resisted the temptation to protest openly against the Roman Empire. Interestingly, Luke does not explicitly state that Paul was a prisoner; rather, he refers to him as 'Paul and some other prisoners' (Ac 27:1), and writes that, 'the soldiers planned to kill the prisoners ... But the centurion wanted to spare Paul's life...' (Ac 27:43-44). Again, Luke's narrative does not acknowledge that Paul was in chains in Acts 21 but he portrays Paul as a prisoner in the chapter.

On the issue of apologetic narrative and conformity to imperialism, the text suggests that in Acts 27, Luke was reluctant to confront the Roman authorities about the challenges that the early Christians faced. Instead of a negative picture of the Roman Empire and its officials, Luke seemed to portray them in a good light: he had a 'good story to tell' narrative about the imperialist Roman government.

\section{Is a supposedly good story always good? A view of Luke's 'we have a good story to tell' narrative about the Roman Empire}

In July 2013, the National Executive Committee (NEC) of South Africa's African National Congress (ANC) came up with a political slogan, 'we have a good story to tell', to kick off the 2014 election campaign (Mantashe 2013:1). President Jacob Zuma argues that the ANC does not need to take serious the political propaganda that the post-apartheid government has achieved nothing since the first democratic elections of 1994 (Zuma 2013:3). His reason is that the ANCled government has a good story to tell in terms of service delivery to the people of South Africa. Mantashe supports Zuma's claim but adds that in telling the good story, the ANC should 'own up for mistakes committed in the postapartheid period - beginning with the negotiations [sic] process' (Mantashe 2013:7). In other words, to address the challenges that the post-apartheid South Africa still faces, it is important to acknowledge the shortcomings of the present government.

Interestingly, Mantashe's statement does not rule out the possibility that there is a need to continue the struggle for holistic liberation although neither he nor Zuma explicitly articulates that need. Instead, with the saying, 'we have a good story to tell' Zuma claims that South Africans have gained democratic freedom since 1994 (Zuma 2013:2). The line in Mickey Mouse freedom, ' $[t]$ hey were told many years ago that their country is free', mimics this claim. However, Lucky Dube's song suggests that South Africa cannot be classified as a country that has attained holistic freedom because of the prevalence of various forms of oppression. In other words, a narrative of freedom in the midst of oppression is unreliable and unconvincing. In view of the tenor underlying the song it can be assumed that a constructed narrative and the projection of 'a good story' might not necessarily mean a good and reliable story. In the same vein, we shall examine therefore Luke's 'we have a good story to tell' narrative about the Roman Empire.

In Acts 27 there does not seem to be any negative comment which puts the Roman Empire or its officials in a bad light. This suggests the possibility of political propaganda which seeks to present the person in power as 'holier than thou': propaganda by nature seeks to present a particular group as good and the opposing party as bad. Is it possible that Luke-Acts contains such propaganda, especially in Acts 27? In his chapter, 'Roman Propaganda and Christian Identity in the Worldview of Luke-Acts', Gilbert (2003:233) sets out to explore the propaganda that favoured the Roman Empire. 
He argues that the Roman Empire employed a rhetorical strategy namely political propaganda with a view to provoke conformity and stability within its domain (Gilbert 2003:236). Thus, there is a need to probe how such propaganda was employed.

The public recognition of the Roman officials as saviours was a strategy to provoke conformity (Gilbert 2003:238239). In other words, the 'we have a good story to tell' narrative about Roman officials projects the view that the Roman Empire was good, and it triggered conformity and loyalty to the empire. Gilbert, in agreement with Magie and Newton, provides evidence for the claim that Roman officials were portrayed as saviours. The inscriptions from Priene, Halicarnassus and Myra, for instance, reveal that Augustus was regarded and praised as the saviour of the whole human race (Newton 1874-1916:4:894; Magie 1950:1:534; Gilbert 2003:238). This form of propaganda was meant to promote loyalty to the Roman mperor. It must have made sense to be loyal to an authoritarian figure which was both a saviour and a benefactor. Thus, in all probability, the Roman Empire was deliberately portrayed as having a 'good story to tell' which supports the view of scholars such as Gilbert, Newton and Magie that political propaganda was used to promote it.

In Acts 27, there seems to be noticeable elements of political propaganda in favour of the Roman Empire. Firstly, a Roman official, Julius is depicted, by Luke obviously, as kind to Paul, a prisoner, for he permitted him to visit his friends (Ac 27:3). It is strange that a jailer or an official of the jail could be kind to the point of letting a prisoner free to visit his friends prior to the trial in a court of law. Secondly, when Paul cautioned the centurion that 'unless the sailors remain in the ship they cannot be saved', it was Julius who listened to Paul the prisoner and caused the sailors to remain (Ac 27:32). Luke therefore presented a Roman official as being responsible for keeping the sailors safe: Paul did not receive any credit for the people's safety; instead Julius is portrayed as the one who saved them.

Thirdly, in verse 43a, Luke writes, 'But the centurion wanted to spare Paul's life and kept them from carrying out their plan'. In this instance, Julius is further presented as Paul's saviour. These three examples seek to present a so-called, 'good story to tell' of the Roman Empire. The portrayal of Julius, a Roman official, as a saviour, fits the rhetoric, 'we have a good story to tell' in Luke's narrative in Acts 27. At this juncture, a critical question to pose is: in view of the various forms of oppression inflicted by the Roman Empire on the early Christians, as argued above, can one genuinely find the rhetoric, 'we have a good story to tell' in the narrative of Acts 27 attractive? The positive and wonderful portrayal of Julius, a Roman official in Acts 27 , is not reconcilable with the reality of oppression in the Sitz-im-Leben of Acts 27. Thus, it is reasonable to argue that the 'good story' about the Roman officials and indeed of the Roman Empire is not so good after all, especially in the light of this life-setting.

\section{Paul in chains, yet prophetic}

In view of the claim that Luke sought to present Christians and Christianity as harmless and supportive of the Roman Empire in Luke-Acts (Gilbert 2006:85), one wonders whether or not his depiction of Paul was important. In other words, why would a writer present a group of people to its oppressors as harmless and loyal and not as frustrated and oppressed? Had the writer portrayed the early Christians in Acts 27 as being frustrated with the imperialist Roman officials, the presentation of Christianity as pro-Roman Empire would be unconvincing. Also, had Luke stressed that Paul was in chains and oppressed, any argument that Christianity supported the empire would not be valid. Portraying Christianity as pro-Roman Empire on the one hand and portraying Paul as oppressed on the other hand would have been a contradiction. Thus, it is most likely that Luke intentionally refrained from calling attention to the fact that Paul was oppressed and indeed in chains because he wanted to present Julius, a Roman official, as a saviour. As Gilbert (2003:238-239) correctly argues, presenting Julius as a saviour was a strategy to show conformity and loyalty to the Roman Empire. Therefore, showing that Paul was free to do certain things such as visiting his friends and publicly advising his jailer was probably part of the political propaganda that aimed to portray early Christians as less oppressed. In that case, it would be imperative to liberate the reality of Paul's chains and oppression from such political propaganda.

Acts 27:1 confirms that Paul was a prisoner which implies that he was in chains and experienced a form of oppression. A number of other texts state explicitly that Paul was in chains (cf. Ac 16:25-26 and Eph 6:20). Contrary to that claim the text also shows that Paul had the liberty to move around and visit his friends (Ac 24:23; 27:3). It is fairly certain that Paul was detained and imprisoned unfairly by the Roman authorities (Ac 21:26-39; 23:33-27:2). Therefore, he was also a victim of incarceration or imprisonment. In Acts 21:22-28 and 25:7-8, the charges against Paul could not be proven; hence, he pleaded not guilty of wrongdoing. The charges were outlined thus: 'For we have found this man a plague, a creator of dissension among all the Jews throughout the world, and a ringleader of the sect of the Nazarenes' (Ac 24:5); and 'He even tried to profane the temple' (Ac 25:6). Since the charges could not be proven and Paul was imprisoned nevertheless, it could be presumed that Paul was unfairly incarcerated and put in chains.

In the early New Testament writings such as the Synoptic Gospels (Matthew, Mark and Luke) a trend of unfair and inhumane treatment of prisoners is evident. A clear example is the treatment of Jesus Christ in his passion and crucifixion. It is interesting that, in Acts 27, Luke presented a Paul who was adored and treated with kindness by the Roman official, as opposed to the Paul who was scourged in Acts 21:40 22:23. As Campbell (2007:78) rightly observes, the Roman officials were, in that instance, hostile to Paul whereas there was no hostility towards him in Acts 27. However, one cannot rule out the possibility of traces of hostility against 
Paul who was shipped to Rome in line with the Roman practice at that time.

Scheffler (2013:136) notes that, 'Paul pursued (besides being an apostle) his own profession as a tent maker in order to be materially independent and have something to give to the poor'. The statement shows that Paul belonged to the middle class which worked hard to survive. The middle class was subject to the payment of tax to the Roman Empire, as the above statement implies. Thus, it is reasonable to argue that Paul also experienced the economic oppression inflicted on the early Christians by the Roman Empire. It is remarkable that in the narrative of Acts 27, Paul was one of the prisoners who did not own food. The food they eventually ate was not theirs; it belonged to the Roman state. ${ }^{6}$ A portrayal of Paul in chains cannot ignore the fact that Paul was in economic captivity, without resources to survive physically, since food was indispensable to their health and physical well-being. He was economically dependent on the Roman Empire's resources.

In light of the tenor behind Lucky Dube's, Mickey Mouse freedom, it seems Paul was not free and he did not support the Roman Empire in Acts 27. Thus, Paul must have experienced false freedom as he had only limited freedom, which should not overshadow the reality of his chains. Paul's relationship with Julius, an official of the Roman Empire, should also not be viewed as a demonstration of his or Christianity's approval of the Roman Empire. In this regard, Gilbert reasons:

It does not necessarily follow, however, that generally harmonious depiction of relations between Christians and Romans implies approval of Rome's imperial claims. Recent analysis of the relations between dominant and subordinate cultures has shown that the absence of active resistance, physical or verbal, on the part of a subordinate group does not hereby convey acceptance or acquiescence to a dominant power. Rather, subordinate groups often develop arts of resistance that are more subtle and nuanced but less real. (Gilbert 2006:86-87)

On the relations between dominant and subordinate cultures, two critical questions to ask are: does Acts 27 illustrate the approval for loyalty to the Roman Empire?; is there evidence in Acts 27 of a subtle resistance that elevates Paul's prophetic voice whilst he was in chains?

In verses 9-11, Paul raises a prophetic voice in the form of a warning. He warns the Roman official, the pilot and the owner of the ship: 'Men, I can see that our voyage is going to be disastrous and bring great loss to ship and cargo, and to our own lives also' (Ac 27:10). As Bruce (1990:515) argues, Paul offered advice to the sailors based mainly on his experience in sailing (2 Cor 11:25). In spite of the credibility of Paul's advice, his warning was disregarded. Instead, the Roman official, Julius, adhered to the voice of the captain and the owner of the ship. It thus appears that Paul's prophetic

6 According to Bruce (1990:513), the ship of Alexandria was a privately owned ship that transported that transported grain from Egypt to Rome, as Egypt was the chief granary of Rome. Moreover, it being privately owned did not mean that the ship was outside state control. The owner of such ships released their services to the state under contract, meaning that private owners could operate under state control (Bruce 1990:513). voice was rejected on account of who he was and not because of the credence of his voice. Had the problem been in the credibility of the advice, Luke would probably have stated that. Thus, it is most likely that the main reason the sailors rejected Paul's warning was on account that he did not own the ship. Instead of being silenced by the earlier rejection of his advice by the Roman official, Paul was even more resilient and persisted in his effort to articulate the prophetic voice. In verse 21 , which states that '... Paul stood up before them and said ...', Luke relates what can be regarded as a 'confrontation' with the official of the Roman Empire.

In an African-conscious female reading of Steve Biko by Masenya (Ngwan'a Mphahlele) (2008:119), it is noted that the oppressor often tends to instil fear in the hearts of the oppressed, as was the case in South Africa during the apartheid regime (cf. Biko 1977:272). Masenya (Ngwan'a Mphahlele) affirms that the oppressed therefore require 'courage and boldness in the face of incarceration and even death' (Masenya [Ngwan'a Mphahlele] 2008:116). Masenya (Ngwan'a Mphahlele) reading of Steve Biko helps us to appreciate and commend Paul's courage as he stood before the Roman official the second time. Thus, Paul continued to raise his prophetic voice in the face of chains and imperialism.

Interestingly, Paul's prophetic voice in Acts 27:21-26 carried both a message of hope and a prophecy of doom. On the one hand, Paul tried to restore hope to those on board by disclosing that an angel of God had assured him in a vision that only the ship would be damaged in the storm (Campbell 2007:82; cf. Ac 27:21-26). The assurance constitutes a message of hope that Paul delivered to his jailer and the owner of the ship. It is noteworthy that whereas Campbell does not explain the basis of Paul's message of hope, Bruce (1990:521) indicates that Paul's reassuring message in Acts 27:23 relied on a special revelation: the source of the message of hope was God's agency, an angel. On the other hand, Paul pronounced a prophecy of doom regarding the destruction ahead of them.

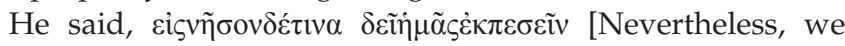
must run aground on some island] (Ac 27:26). His prophetic voice sounded not just a message of hope about their safety but also a message of doom about the destruction of the ship. One would expect that, since he was in chains, Paul would not make a statement that would infuriate his oppressor. However, he was not afraid to prophesy doom even when it appeared unwise to do so.

After Paul's last address during the sea voyage to Rome, 'he took some bread and gave thanks to God in front of them all. Then he broke it and began to eat' (Ac 27:35). That act of breaking bread and sharing a meal has caught the attention of Luke-Acts commentators. Tannehill (1990:334-335) notes that the meal mentioned in Acts 27:35-37 echoes the motif of sacramental meals in Luke-Acts such as the feeding of the multitude and the supper on the way to Emmaus in Luke 9:16 and 24:30 respectively. Campbell agrees with Tannehill that the meal in Acts 27 contained a Eucharistic motif or element. In other words, 'Eucharistic overtones 'can be detected in the act of breaking bread and the sharing of a 
meal, which was conducted by Paul (Campbell 2007:82; cf. Ac 27:35-37). However, some scholars disagree with this claim (Haenchen 1971:707; Conzelmann 1987:220; Bruce 1990:525). In their view, the meal of Acts 27 does not echo the Eucharist. Bruce (1990:525) finds a middle ground and argues that, for those who ate the meal with Eucharistic intentions it was a valid Eucharist and for others it was just an ordinary meal. However, he does not offer a convincing explanation of the breaking of bread and the sharing of meal in Acts 27. Finger (2007) attempts to rectify that oversight:

\footnotetext{
... the ship's passengers in Acts 27, who come from various social strata (including prisoners) ... experience social reversal as one who has been in chains among them takes the lead in hosting a meal and urging commensality. (p. 240)
}

Finger points out that the one who was the chief victim of oppression now took the lead in sharing a meal. Paul facilitates an act that would result in their survival. Moreover, instead of watching the others continue without food, as the Roman officials had done, Paul initiated and facilitated the process of sharing their meagre resource, in this instance, the bread. The act confirmed Paul's prophetic role and witness whilst he was still in chains. As argued above, the meal of Acts 27 relates to that of Acts 6 where the motif of 'Lukan table fellowship' is evident. In the use of that motif, the disciples are called 'to wait on tables' (Ac 6:2). For Pao (2011:139), the move provides an opportunity for both the oppressed and the oppressor to share a meal equally. In other words, being prophetic, as Paul has demonstrated in Acts 27, requires that the disciples play the role of a 'waiter', with the goal of reconciling the oppressed with the oppressor and fostering the equitable sharing of resources.

\section{Conclusion - lessons from Acts 27 on liberationist prophetic voice in the context of oppression}

This paper has attempted to show the harsh reality of various forms of oppression (chains) and the prophetic voice that spoke to such oppression in Acts 27. In this regard, it tries to determine the type of society in which Luke-Acts had its setting, that is, the Sitz-im-Leben of Acts 27. The reality of imperialism in the Roman Empire was marked by forceful payment of taxes to the empire, mass incarcerations and crucifixion which instilled fear in the early Christians, and poverty, amongst other forms of oppression.

On the one hand, this essay set out to probe whether Acts 27 represents an apologetic narrative. It noted that Luke refrained from challenging the various forms of oppression inflicted on the early Christians and on Christianity by the empire. Rather than addressing oppression, the political propaganda which presented the Roman officials as saviours with a so-called 'good story to tell 'in Acts 27 is clear. Thus, we agree that Luke presented an apologetic narrative in Acts 27. On the other hand, Paul's prophetic skill is also evident in Acts 27. Although in chains, Paul remained prophetic. Lucky Dube's Mickey Mouse freedom song which has been employed as a hermeneutic tool to unlock the meaning of Acts 27 therefore allows us to draw the following conclusions:

The text of Acts 27 is set in the context of various forms of oppression.

- It is probable that early writers of the New Testament such as Luke were prohibited from writing freely under the imperialist rule of the Roman Empire.

- The rhetoric, 'we have a good story to tell' in the narrative of Acts 27 does not imply that oppression did not exist.

- Paul persisted in raising the prophetic voice in the face of imperialism and chains (oppression).

It is indeed possible to read ancient texts in favour of the oppressed, and an African liberationist reading of Paul in Acts 27 does take into account the interests of the oppressed in the present day South Africa.

\section{Acknowledgements}

I would like to thank my God, whose grace sustains me in my scholarship. Much gratitude goes to my lovely wife, Siphumle (Manzimande) for her continued support.

\section{Competing interests}

The author declares that he has no financial or personal relationship(s) that may have inappropriately influenced him in writing this article.

\section{References}

Biko, S., 1977, 'Fear - an important determinant in South African politics', in M.W. Arnold (ed.), The testimony of Steve Biko, pp. 271-283, M.T. Smith, London.

Bruce, F.F., 1990, The Acts of the Apostles: The Greek text with introduction and commentary, Wm. B. Eerdmans, Grand Rapids.

Campbell, W.S., 2007, The 'We' passages in the Acts of the Apostles: The narrator as narrative character, Society of Biblical Literature, Atlanta.

Conzelmann, H., 1987, Acts of the Apostles: A commentary on the Acts of the Apostles, Fortress Press, Philadelphia.

Dube, L., 1992, House of exile, Gallo Record, Johannesburg.

Finger, R.H., 2007, Of widows and meals: Communal meals in the book of Acts, Wm. B. Eerdmans, Grand Rapids.

Fitzmyer, J.A., 1992, Romans, AB.33, Doubleday, New York.

Forbush, W.B., 1926, Fox's book of martyrs: A history of the lives, sufferings and triumphant deaths of the early Christian and Protestant martyrs, Universal Book and Bible House, Philadelphia.

Gilbert, G., 2003, 'Roman propaganda and Christian identity in the worldview of LukeActs', in T.C. Penner \& C.V. Stichele (eds.), Contextualizing Acts: Lukan narrative and Greco-Roman discourse, pp. 233-256, Society of Biblical Literature, Atlanta.

Gilbert, G., 2006, 'Luke-Acts and negotiation of authority and identity in the Roman world', in C. Helmer (ed.), The multivalence of biblical texts and theological meanings, pp. 83-104, Society of Biblical Literature, Atlanta.

Green, D.E., 2004, 'The folly of the cross', The Master's Seminary Journal 15(1), 59-69.

Gregory, A.F., 2003, The reception of Luke and Acts in the period before Irenaeus, WUNT 2/169, Mohr Siebeck, Tubingen.

Guthrie, D., 1970, New Testament introduction, 3rd edn., Tyndale, London.

Haenchen, E., 1971, The Acts of the Apostles: A commentary, Westminster Press, Philadelphia.

Josephus, T.F., 1956, 'The Jewish war', in T.E. Pages (ed.), The Jewish war, books i-iii, H.J. Thackeray (trans.), pp. 11-790, William Heinemann Ltd, London and Massachusetts, Harvard University Press, Cambridge.

Kelber, W.H., 2004, 'Roman imperialism and early Christian scribality', in J.A. Draper (ed.), Orality, literacy and colonialism in antiquity, pp. 135-154, Society of Biblical Literature, Atlanta.

Larkin, Jr, W.J., 2000, 'The recovery of Luke-Acts as "grand narrative" for the Church's evangelistic and edification tasks in postmodern age', Journal of the Evangelical Theological Society 43(3), 405-415. 
Loba-Mkole, J., 2005, 'The social setting of Jesus' exaltation in Luke-Acts (Lk 22:69 and Ac 7:56)', HTS Theological Studies 61(1/2), 291-326.

MacDonald, D.R., 2012, Two shipwrecked gospels: The logio of Jesus and Papais's exposition of logia about the Lord, Society of Biblical Literature, Atlanta.

Magie, D., 1950, Roman rule in Asia minor to the end of the third century after Christ vol. 2, Princeton University Press, Princeton.

Mantashe, G., 2013, 'Bringing about a national democratic society', ANC NEC Lekgotla Bulletin, 6-7.

Masenya (Ngwan'a Mphahlele), M., 2001a, 'Between unjust suffering and the "silent" God: Job and HIV/AIDS sufferers in South Africa', Missionalia 29, 186-199.

Masenya (Ngwan'a Mphahlele), M., 2001b, 'A bosadi (womanhood) reading of Proverbs 31:10-31', in M.W. Dube (ed.), Other ways of reading: African women and the Bible, pp. 114-155, Society of Biblical Literature and WCC Publications, Atlanta and Geneva.

Masenya (Ngwan'a Mphahlele), M., 2008, 'An African-conscious female's reading of Steve Biko', in C.W. du Toit (ed.), The legacy of Stephen Bantu Biko: Theological challenges, pp. 114-155, Research Institute for Religion and Theology, University of South Africa, Pretoria.

Mosala, I.J., 1989, Biblical hermeneutics and black theology in South Africa, Wm. B. Eerdmans, Grand Rapids.

Mtshiselwa, N., 2011, 'Towards an indigenous (Xhosa) South African biblica scholarship', Old Testament Essays 24(3), 668-689.

Nasrallah, L., 2008, 'The Acts of the Apostles, Greek cities, and Hadrian's panhellenion', Journal of Biblical Literature 127(3), 533-566.

Newton, C.T., 1874-1916, The collection of ancient Greek inscriptions in the British museum, vol. 4, British Museum, London.

Nkoala, S.M., 2013, 'Songs that shaped the struggle: a rhetorical analysis of South African struggle songs', African Yearbook of Rhetoric 4(1), 51-61.
Ottermann, M., 2007, "“How could he ever do that to her?!" Or, how the woman who anointed Jesus became a victim of Luke's redaction and theological principles', in G.O. West (ed.), Reading other-wise: socially engaged biblical scholars reading in G.O. West (ed.), Reading other-wise: socially engaged biblical scholars reading
with their local communities, pp. 103-116, Society of Biblical Literature, Atlanta.

Pao, D.W., 2011, 'Waiters or preachers: Acts 6:1-7 and the Lukan table fellowship motif', Journal of Biblical Literature 130(1), 127-144.

Pervo, R.I., 2000, 'My happy home: The role of Jerusalem in Acts 1-7', Forum 3(1), $31-55$.

Pervo, R.I., 2006, Dating Acts: Between the evangelists and the apologists, Polebridge, Santa Rosa.

Pervo, R.I., 2008, Acts: A commentary, Fortress, Hermeneia.

Pesthy, M., 1998, 'Cross and death in the Apocryphal Acts of the Apostles', in J.N. Bremmer (ed.), The Apocryphal Acts of Peter, pp. 123-133, Peeters, Leuven.

Redekop, M., 1993, 'Escape from the bloody theatre: The making of Mennonite stories', Journal of Mennonite Studies 11, 9-22.

Scheffler, E., 1993, Suffering in Luke's gospel, Theologischer Verlag, Zürich.

Scheffler, E., 2013, 'Poverty eradication and the Bible in context: A serious challenge', Studia Historiae Ecclesiasticae 39 (Supplement), 129-153.

Sterling, G.E., 1992, Historiography and self-definition: Josephus, Luke-Acts and apologetic historiography, NovTSup 64, Brill, Leiden. http://dx.doi. org/10.1163/9789004266940

Sugirtharajah, R.S., 1999, 'Thinking about vernacular hermeneutics sitting in a metropolitan study', in R.S. Sugirtharajah (ed.), Vernacular hermeneutics, pp. 92-115, Sheffield Academic Press, Sheffield.

Tannehill, R.C., 1990, The narrative unity of Luke-Acts: A literary interpretation, The Acts of the Apostles, vol. 2, Augsburg Fortress, Minneapolis.

Zuma, J., 2013, 'The ANC makes SA a successful and thriving democracy', ANC NEC Lekgotla Bulletin, 2-5. 